nearly all of them to consult with university sociologists before acting on a proposal. This means that academic representatives maintain the main part of the control over available funds.

In Europe it is, on the whole, more difficult to get subsidies for research than subsidies for the publication of research. In spite of the great amount of support for research in the United States, there is both proportionately and absolutely little subsidy to publish scholarly reports. This means that the number of monographic reports published in the United States is lower than one would expect in view of the total volume of research. Elementary textbooks appear to be about the only risks that most commercial publishers are willing to take. To simplify the students' task of locating important articles, a number of so-called 'readers' have appeared during the past decade which reprint in book form a series of articles related to a given topic.

In a survey of recent research projects in American sociology, Zetterberg shows that the common charge that sociology merely elaborates the obvious is often without justification. For example, it has been generally held that insanity-rates have increased as society becomes more urbanized and industrialized. Goldhamer and Marshall have shown that over the past century in the State of Massachusetts there has been no such increase. Numerous commentators have expressed the view that the rate of social mobility has declined over the past decades in the United States. The study of intergenerational occupational mobility by Rogoff and the study of access to the business élite by Keller show no general decline, although the avenues to success might be different from in the past. It has long been an axiom that the rate of social mobility is higher in the United States than in Western Europe : examination of the available evidence by Lipset and Rogoff fails to sustain this belief. Democratic ideologists have glorified the voter who first listens to all the arguments and then makes up his independent mind to deliver his vote. The election studies by Lazarsfeld et $a l$. and Berelson et al. show that group pressures in most cases determine the way the vote is cast and that the voter who does not make up his mind until the campaign is over is likely to be the least informed and the most confused.

The rest of the book gives detailed surveys of work which has been carried out in the past decade or so under the headings of method and theory, social institutions and groups, rural and urban sociology, sociology of social stratification, criminology, sociology of ethnic relations and the sociology of mental health.

\section{TRIGONIA: A LIVING FOSSIL}

A $T$ the close of the Mesozoic era the bivalve A Trigonia gradually became less abundant in European seas and, to all appearances, soon became extinct. Their shells do not occur as fossils in the rocks formed during Tertiary time, and geologists were convinced that they had died out. Donald F. MeMichael has described how the French naturalist, Peron, who, with his fellow collectors on the voyage of the French exploration ship Geographe, found on a beach in southern Tasmania a shell which seemed to be the same as well-known fossils. Back in France, the great zoologist, Lamarck, described the shell as the first living Trigonia, calling it $T$. margaritacea because of its beautiful iridescent interior (Aust. Mus. Mag., 12, No. $3 ; 1956$ ).

Two other French naturalists, Quoy and Gaimard, who sailed with the Astrolabe, carried out searches for a living specimen. In King George's Sound and in Westernport, Victoria, occasional dead valves were found, but none alive. The first was hauled up in Bass Strait, among deep-sea animals and debris, and this was followed by other living specimens. The discovery of these living fossils must have excited as much interest at the time as did the finding of the first living coelacanth. It was as important from the scientific point of view.

The shells are placed in a separate family, the Trigoniidae, which includes a number of different genera, and many distinct species. Of these, only six are living to-day, and all are found along the Australian coast. Later research has revealed that the shells do occur as fossils in the Tertiary rocks of Australia, where alone they have persisted since Mesozoic time.

The present-day species are placed in the genus Neotrigonia. Because of their delightful lustre, the common name for them is brooch shells, and they are used for shell jewellery. The exterior of the shell is marked with a series of radiating ridges and nodules, and the hinge 'teeth' are large and strongly serrated; these features are characteristic of the group.

All the living species of Neotrigonia occur in fairly deep water, between 10 and 100 fathoms, and only dead shells are seen on the beaches after storms.

\section{PHOSPHATE FERTILIZERS}

TN a recent publication* by the Organization for - European Economic Co-operation, results of all suitable experiments in Western Europe that compare phosphate fertilizers made by processes which economize in sulphuric acid with other well-known phosphates have been collected and correlated by G. W. Cooke. The report is based on summaries of work carried out in their countries by rapporteurs from the Low Countries, Scandinavia, Austria, France, Germany, Italy, Portugal, Switzerland, Ireland and the United Kingdom. Occasional reference is made to comparable experiments in the United States.

The report emphasizes that the values of altern. ative phosphate fertilizers depend on the crops for which they are applied; unprocessed rock phosphates are satisfactory, for example, for swedes on acid soils, but potatoes make little use of this fertilizer and require water-soluble phosphates. The evaluation of fertilizers in both pot and field experiments is de. scribed, but most of the conclusions are based on extensive series of field experiments; results from 379 experiments with dicalcium phosphate and 537 experiments with phosphates produced by thermal processes are summarized in the report.

The main classes of phosphate fertilizers discussed are dicalcium phosphate, nitrophosphates, phosphates produced by high-temperature processes and com. pound fertilizers containing ammonium phosphates. Powdered dicalcium phosphate dihydrate is equiva. lent to superphosphate. Nitrophosphates that con-

* "The Agricultural Value of Phosphate Fertllizers which economize in the Use of Sulphuric Acid". By Dr. George W. Cooke, Rothamsted Experimental Station, Project No. 162. (Organization for European 